\title{
Hubungan Antara Gaya Belajar, Kemandirian Belajar, dan Minat Belajar dengan Hasil Belajar Biologi Siswa
}

\author{
Nurlia, Yusminah Hala, Rachmawaty Muchtar, Oslan Jumadi, A. Mushawwir Taiyeb \\ Program Studi Pendidikan Biologi, Program Pascasarjana, Universitas Negeri Makassar, Indonesia \\ E-mail: nurlia2811@gmail.com
}

\begin{abstract}
The students' learning results in Biology are influenced by two factors, namely internal and external factors. The internal factors that can influence learning results are learning style, learning independence, and learning interest. The research aims to discover the relation of learning style, learning independence and learning interest with Biology learning results of the students at SMAN 1 Tonra in Bone District.The research is ex post facto. The population of the research were the students of class IPA at SMAN 1 Tonra in Bone District of academic year 2016/2017. The samples were 194 students taken by using stratified random sampling technique. Data were collected by employing questionnaire and documentation. The data of the research were analyzed by using descriptive and inferential statistics techniques. The results of the research reveal that (i) the students' learning style tends to be in visual type, (ii) the students' learning independence is in high category, (iii) the students' learning interest is in high category, (iv) the students' Biology learning results is in high category, (v) there is strong relation between learning style and the students' Biology learning results, (vi) there is fairly strong relation between learning independence and the students' Biology learning results, (vii) there is strong relation between learning interest and the students' Biology learning results, and (viii) there is very strong relation between learning style, learning independence, and learning interest toword Biology learning results of the students at SMAN 1 Tonra in Bone District.
\end{abstract}

Key Words: Biology Learning Results, Learning Independence, Learning Interest, Learning Style

\section{PENDAHULUAN}

Belajar adalah suatu proses usaha yang dilakukan seseorang untuk memperoleh suatu perubahan tingkah laku yang baru secara keseluruhan, sebagai hasil pengalamannya sendiri dalam interaksi dengan lingkungannya (Slameto, 2015). Kemampuan yang diperoleh seseorang setelah melalui kegiatan belajar disebut sebagai hasil belajar. Menurut Susanto (2013), hasil belajar siswa dipengaruhi oleh dua faktor yakni, faktor internal dan faktor eksternal. Faktor internal meliputi kemampuan berpikir atau tingkah laku intelektual, motivasi, minat dan kesiapan siswa, baik jasmani maupun rohani. Sedangkan faktor eksternal meliputi sarana dan prasarana, kompetensi guru, kreativitas guru, sumber-sumber belajar, metode serta dukungan lingkungan, keluarga dan lingkungan.

Secara keseluruhan dapat diketahui bahwa semua faktor tersebut dapat mempengaruhi hasil belajar siswa. Salah satu karakteristik siswa yang berpengaruh terhadap hasil belajar adalah gaya belajar. Gaya belajar sangat penting dan sangat menentukan bagi siapapun dalam melaksanakan tugas belajarnya, siapapun dapat belajar dengan lebih mudah, ketika ia menemukan gaya belajar yang cocok dengan dirinya (Marpaung \& Napitupulu, 2014). Menurut DePorter \& Hernacki (2015) gaya belajar seseorang adalah kombinasi dari bagaimana ia menyerap, dan kemudian mengatur serta mengolah informasi.

Kemandirian belajar merupakan faktor yang mempengaruhi hasil belajar siswa. Siswa yang memiliki kemandirian belajar yang tinggi akan berusaha menyelesaikan tugas yang diberikan oleh guru, sebaliknya siswa yang memiliki kemandirian belajar yang rendah akan tergantung pada orang lain (Fitriana et al, 2015). Kemandirian belajar merupakan kesiapan dari individu yang mau dan mampu untuk belajar dengan inisiatif sendiri, dengan atau tanpa bantuan pihak lain dalam hal penentuan tujuan belajar, metode belajar, dan evaluasi hasil belajar (Tahar \& Enceng, 2006).

Minat pada dasarnya merupakan salah satu faktor yang mempengaruhi hasil belajar. Pada situasi belajar mengajar di sekolah, siswa yang berminat terhadap suatu mata pelajaran tertentu akan cenderung untuk memusatkan perhatian secara terus-menerus selama belajar mengajar berlangsung (Syah, 2014). Menurut Khairani (2014) minat adalah gejala psikologis yang menunjukkan bahwa minat adanya pengertian subyek terhadap obyek yang menjadi sasaran karena obyek tersebut menarik perhatian dan menimbulkan perasaan senang sehingga cenderung kepada obyek tersebut.

Hasil observasi yang diperoleh dariwawancara dengan guru mata pelajaran 
Biologi di SMA Negeri 1 Tonra Kabupaten Bone, bahwa masalah yang paling pokok adalah hasil belajar Biologi siswa yang kurang maksimal, sehingga terkadang dilakukan remedial untuk memperbaiki hasil belajar siswa.

Fakta yang diperoleh peneliti bahwa di SMA Negeri 1 Tonra Kabupaten Bone belum pernah dilakukan penelitian tentang gaya belajar, kemandirian belajar dan minat belajar siswa. Selain itu, diperoleh informasi bahwa sebagian siswa masih menganggap bahwa Biologi adalah mata pelajaran yang susahkarena materinya banyak, harus dihapal serta identik dengan bahasa latin. Dalam proses pembelajaran Biologi siswa sering kali menempuh cara yang berbeda untuk dapat memahami materi pelajaran yang sama. Ada siswa yang monoton mencatat apa yang dikatakan oleh guru, ada juga siswa yang hanya mendengar penjelasan dari guru, dan ada siswa yang aktif bergerak sehingga terlibat langsung dalam proses pembelajaran. Hal tersebut menunjukkan bahwa setiap siswa dalam menerima pelajaran Biologi menggunakan gaya belajar yang berbeda-beda.

Kemandirian belajar siswa berperan sebagai penunjang dalam mencapai tujuan pembelajaran. Siswa yang memiliki kemandirian belajar yang tinggi diharapkan mampu belajar dengan baik sehingga menguasai materi pelajaran dan meningkatkan hasil belajar Biologinya. Hasil observasi diperoleh bahwa kemandirian belajar yang dimiliki setiap siswa berbeda-beda ditandai pada saat pemberian tugas rumah, ada siswa yang dapat mengerjakan tugas dengan baik tanpa bantuan orang lain tetapi masih ada beberapa siswa yang menyelesaikan tugas di sekolah dengan melihat pekerjaan teman yang sudah selesai. Jika diberikan tes ujian tertulis oleh guru ada siswa yang mampu menyelesaikan soal dengan baik tetapi ada pula siswa yang menyontek jawaban temannya.

Faktor lain yang menunjang pencapaian hasil belajar siswa adalah minat belajar. Siswa yang memiliki minat belajar yang tinggi diharapakan dapat terus belajar dengan tekun sehingga dapat meningkatkan hasil belajar Biologinya. Hasil observasi yang diperoleh bahwa minat belajar yang dimiliki setiap siswa berbeda-beda ditandai pada saat proses pembelajaran ada siswa yang mendengarkan penjelasan guru dengan baik tetapi ada siswa cenderung memilih untuk mengobrol dengan teman sebangkunya dibanding mendengarkan penjelasan guru, selain itu ada siswa yang selalu antusias dan terlibat tanya jawab di kelas tetapi ada siswa yang jarang bertanya kepada guru baik saat di kelas maupun di luar kelas.

Tujuan penelitian ini untuk mengetahui hubungan antara gaya belajar, kemandirian belajar dan minat belajar dengan hasil belajar Biologi siswa SMA Negeri 1 Tonra Kabupaten Bone".

\section{METODE PENELITIAN}

Jenis penelitian ini adalah penelitian ex post facto dan bersifat korelasional yang dilakukan untuk meneliti variabel yang telah terjadi tanpa perlu memberikan perlakuan terhadap variabel tersebut. Variabel penelitian terdiri dari tiga variabel bebas yakni gaya belajar $\left(\mathrm{X}_{1}\right)$, kemandirian belajar $\left(\mathrm{X}_{2}\right)$, minat belajar $\left(\mathrm{X}_{3}\right)$, dan satu variabel terikat yaitu hasil belajar Biologi (Y).

Populasi dalam penelitian ini adalah seluruh siswa kelas IPA SMA Negeri 1 Tonra Kabupaten Bone tahun pelajaran 2016/2017 yang berjumlah 376 siswa. Teknik pengambilan sampel dalam penelitian ini adalah stratified random sampling. Secara stratified, anggota populasi dipisahkan berdasarkan tingkatan kelas yaitu kelas X MIPA, XI IPA dan XII IPA. Secara random, sampel dipilih dengan mengundi semua siswa yang menjadi anggota populasi dari setiap tingkatan kelas sampai jumlah sampel yang diinginkan, yakni sebanyak 194 siswa.

Instrumen yang digunakan dalam penelitian ini adalah angket dan dokumentasi. Pengumpulan data gaya belajar, kemandirian belajar, dan minat belajar dilakukan melalui pemberian angket kepada siswa. Data hasil belajar siswa diperoleh dari nilai ujian semester ganjil tahun ajaran 2016/2017. Data yang telah terkumpul dianalisis dengan menggunakan analisis statistik deskriptif dan inferensial dengan uji korelasi dan regresi menggunakan program SPSS 16.0 for windows. 


\section{HASIL DAN PEMBAHASAN}

Hasil analisis deskriptif tipe gaya belajar siswa disajikan dalam bentuk diagram pada Gambar 1.

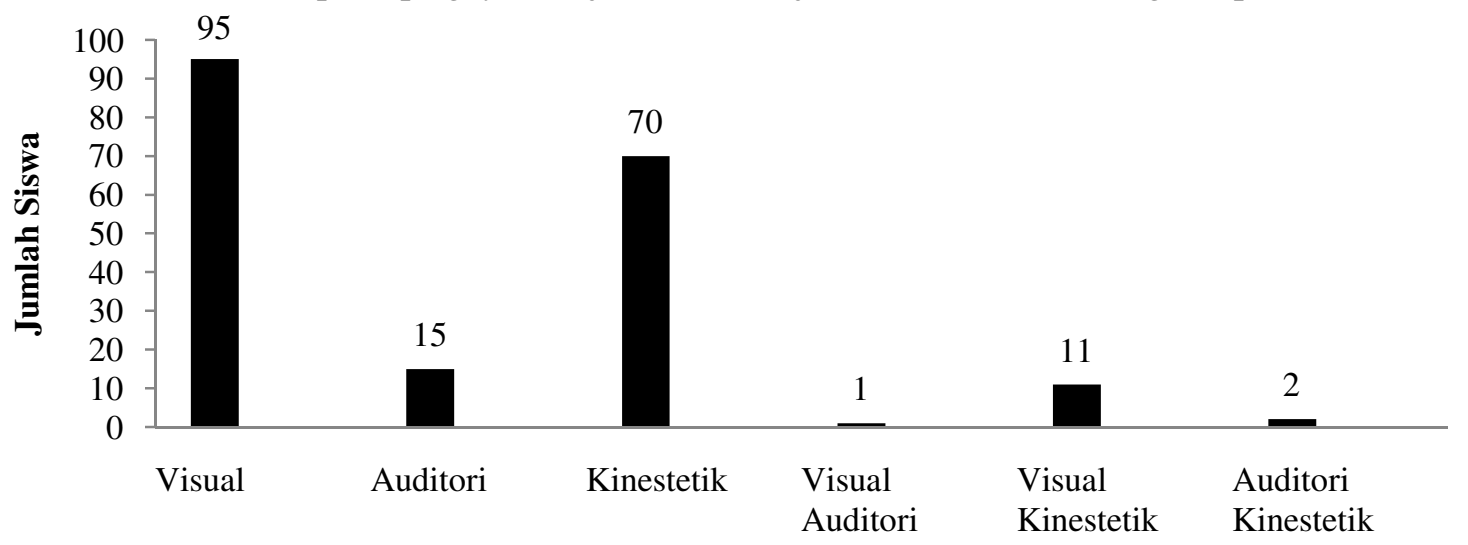

Tipe Gaya Belajar

Gambar 1. Tipe Gaya Belajar Siswa SMA Negeri 1 Tonra Kabupaten Bone

Hasil analisis deskriptif data gaya belajar siswa yang terdiri dari 194 responden menggambarkan bahwa tipe gaya belajar siswa SMA Negeri 1 Tonra Kabupaten Bone pada umumnya berada pada tipe gaya belajar visual, yaitu sebanyak 95 siswa. Gaya belajar siswa umumnya pada tipe gaya belajar visual dapat disebabkan oleh beberapa faktor, salah satu diantaranya adalah faktor kebiasaan. Kecenderungan guru Biologi mengajar dengan menulis materi pelajaran di papan tulis, menggunakan teknik mencatat, menggunakan gambar (carta), serta menganjurkan siswa untuk membaca buku paket dan LKS, merupakan beberapa hal yang dapat mempengaruhi sehingga siswa cenderung mengembangkan tipe gaya belajar visual.

Menurut Bire, et al (2014), gaya belajar visual adalah salah satu gaya belajar siswa yang pada dasarnya lebih menekankan pada bagaimana seorang siswa lebih mudah mempelajari materi pelajarannya melalui melihat, memandangi, atau mengamati objek belajarnya. Hal tersebut bertujuan untuk membantu siswa memusatkan perhatiannya untuk memahami materi yang dipelajarinya.

Hasil analisis deskriptif kemandirian belajar siswa yang meliputi distribusi jumlah, persentase dan kategori disajikan pada Tabel 1.

Tabel 1. Distribusi Jumlah dan Persentase Nilai Kemandirian Belajar Siswa SMA Negeri 1 Tonra Kabupaten Bone

\begin{tabular}{cccccl}
\hline & Interval & & Jumlah & Presentase & Kategori \\
\hline 30 & - & 60 & 0 & $0 \%$ & Sangat Rendah \\
61 & - & 80 & 0 & $0 \%$ & Rendah \\
81 & - & 100 & 29 & $15,0 \%$ & Sedang \\
101 & - & 120 & 130 & $67,0 \%$ & Tinggi \\
121 & - & 150 & 35 & $18,0 \%$ & Sangat Tinggi \\
\hline \multicolumn{2}{r}{} & Total & 194 & $100 \%$ & \\
\hline
\end{tabular}

Hasil analisis deskriptif kemandirian belajar yang terdiri dari 194 responden menggambarkan bahwa kemandirian belajar siswa SMA Negeri 1 Tonra Kabupaten Bone berdasarkan pengkategorian variabel kemandirian belajar berada pada kategori tinggi, yakni mencapai 67,0\%. Kemandirian belajar siswa yang tinggi dapat disebabkan beberapa hal, yakni siswa memiliki rasa percaya diri yang tinggi dalam menyelesaikan tugas dan soal Biologi, keinginan siswa untuk memperoleh nilai Biologi yang tinggi, cara mengajar guru yang menarik, serta kelengkapan sumber dan media pembelajaran baik di sekolah maupun di rumah.

Menurut Thoha dalam Sundayana (2016), terdapat delapan ciri kemandirian belajar, yaitu: mampu berfikir secara kritis, kreatif dan inovatif, tidak mudah terpengaruh oleh pendapat orang lain, tidak lari atau menghindari masalah, memecahkan masalah dengan berfikir yang mendalam, apabila menjumpai masalah 
dipecahkan sendiri tanpa meminta bantuan orang lain, tidak merasa rendah diri apabila harus berbeda dengan orang lain, berusaha bekerja dengan penuh ketekunan dan kedisiplinan, serta bertanggung jawab atas tindakannya sendiri.

Hasil analisis deskriptif minat belajar siswa yang meliputi distribusi jumlah, persentase dan kategori disajikan pada Tabel 2.

Tabel 2. Distribusi Jumlah dan Persentase Nilai Minat Belajar Siswa SMA Negeri 1 Tonra Kabupaten Bone

\begin{tabular}{cccccl}
\hline & Interval & & Jumlah & Presentase & Kategori \\
\hline 30 & - & 60 & 0 & $0 \%$ & Sangat Rendah \\
61 & - & 80 & 0 & $0 \%$ & Rendah \\
81 & - & 100 & 33 & $17,0 \%$ & Sedang \\
101 & - & 120 & 104 & $53,6 \%$ & Tinggi \\
121 & - & 150 & 57 & $29,4 \%$ & Sangat Tinggi \\
\hline \multicolumn{7}{r}{} & Total & 194 & $100 \%$ & \\
\hline
\end{tabular}

Hasil analisis deskriptif minat belajar yang terdiri dari 194 responden menggambarkan bahwa minat belajar siswa SMA Negeri 1 Tonra Kabupaten Bone berdasarkan pengkategorian variabel minat belajar berada pada kategori tinggi, yakni mencapai $53,6 \%$. Minat belajar yang tinggi dapat disebabkan oleh beberapa hal, yakni siswa merasa tertarik dengan materi pelajaran Biologi, siswa merasa bahwa dengan belajar Biologi dapat memberikan manfaat bagi dirinya, keinginan siswa yang besar untuk menguasai materi pelajaran Biologi agar memperoleh nilai yang tinggi, merasa senang dengan cara mengajar guru mata pelajaran Biologi serta kelengkapan sarana dan prasarana di sekolah.

Menurut Saleh, et al (2015), penggunaan media alat peraga sebagai salah satu sarana belajar dapat meningkatkan perhatian siswa terhadap materi pembelajaran yang dibahas. Hasil penelitian yang diperoleh menunjukkan bahwa penggunaan media alat peraga berpengaruh terhadap hasil belajar Biologi siswa.

Hasil analisis deskriptif hasil belajar Biologi siswa yang meliputi distribusi jumlah, persentase dan kategori disajikan pada Tabel 3.

Tabel 3. Distribusi Jumlah dan Persentase Hasil Belajar Siswa SMA Negeri 1 Tonra Kabupaten Bone

\begin{tabular}{cccccl}
\hline & Interval & & Jumlah & Presentase & Kategori \\
\hline 0 & - & 40 & 0 & $0 \%$ & Sangat Rendah \\
41 & - & 55 & 0 & $0 \%$ & Rendah \\
56 & - & 70 & 49 & $25,3 \%$ & Sedang \\
71 & - & 85 & 144 & $74,2 \%$ & Tinggi \\
86 & - & 100 & 1 & $0,5 \%$ & Sangat Tinggi \\
\hline \multicolumn{7}{r}{} & Total & & 194 & $100 \%$ & \\
\hline
\end{tabular}

Hasil analisis deskriptif hasil belajar siswa yang terdiri dari 194 responden menggambarkan bahwa tingkat hasil belajar siswa SMA Negeri 1 Tonra Kabupaten Bone berdasarkan pengkategorian tingkat hasil belajar berada pada kategori tinggi, yakni mencapai $74,2 \%$. Hasil penelitian yang diperoleh menunjukkan hasil belajar siswa termasuk dalam kategori tinggi. Hal ini menandakan bahwa siswa telah mengusai materi pelajaran Biologi dengan baik.

Menurut Djamarah (2010), untuk mengukur keberhasilan proses pembelajaran dibagi atas beberapa tingkatan taraf, yakni: 1) istimewa, apabila seluruh bahan pelajaran yang diajarkan dapat dikuasai oleh siswa, 2) baik sekali, apabila sebagian besar $(76 \%-99 \%)$ bahan pelajaran yang diajarkan dapat dikuasai siswa, 3) baik, apabila bahan pelajaran yang diajarkan (60\% - 75\%) saja yang dikuasai siswa, dan 4) kurang, apabila bahan pelajaran yang diajarkan kurang dari $60 \%$ yang dikuasai oleh siswa. Menurut Sudjana (2013) hasil belajar adalah kemampuan-kemampuan yang dimiliki siswa setelah ia menerima pengalaman belajarnya.

Hasil analisis inferensial untuk mengetahui hubungan antara masing-masing variabel bebas dengan variabel terikat dan hubungan variabel bebas secara bersama-sama dengan variabel terikat disajikan pada Tabel 4. 
Tabel 4. Hasil Analisis Hubungan antara Gaya Belajar, Kemandirian Belajar, dan Minat Belajar dengan Hasil Belajar Biologi Siswa SMA Negeri 1 Tonra Kabupaten Bone

\begin{tabular}{lccc}
\hline \multicolumn{1}{c}{ Analisis Korelasi } & Nilai R & Nilai R $^{\mathbf{2}}$ & Nilai KP \\
\hline Hubungan gaya belajar dengan hasil belajar Biologi & 0,665 & 0,443 & $44,3 \%$ \\
Hubungan kemandirian belajar dengan hasil belajar Biologi & 0,591 & 0,349 & $34,9 \%$ \\
Hubungan minat belajar dengan hasil belajar Biologi & 0,755 & 0,570 & $57,0 \%$ \\
$\begin{array}{l}\text { Hubungan gaya belajar, kemandirian dan minat belajar dengan } \\
\text { hasil belajar Biologi }\end{array}$ & 0,849 & 0,720 & $72,0 \%$ \\
\hline
\end{tabular}

Hasil analisis hubungan antara gaya belajar dengan hasil belajar Biologi diperoleh nilai koefisien korelasi (r) sebesar 0,665. Maka diketahui bahwa hubungan antara kedua variabel tersebut berada pada kategori kuat. Hubungan nyata antara gaya belajar dengan hasil belajar Biologi ditandai dengan nilai signifikansi sebesar 0,000 . Nilai koefisien determinasi sebesar $44,3 \%$, berarti bahwa gaya belajar siswa memberikan kontribusi sebesar 44,3\% terhadap hasil belajar Biologi.

Hasil penelitian menunjukkan adanya hubungan yang kuat antara gaya belajar dengan hasil belajar Biologi berarti bahwa gaya belajar memberikan kontribusi terhadap hasil belajar Biologi. Namun, setiap siswa memiliki cara yang berbeda dalam menerima dan memahami materi pelajaran yang diberikan. Oleh karena itu, siswa harus mengenal, memahami dan mengembangkan gaya belajarnya, sehingga dapat memilih cara belajar yang baik yang sesuai dengan diri mereka, yang akan berdampak positif terhadap hasil belajar Biologi.

Gaya belajar merupakan suatu sikap pribadi yang cenderung menetap dalam mempersepsikan suatu stimulus atau rangsangan tertentu dari lingkungan, selanjutnya memanfaatkannya secara unik dan personal dalam berinteraksi dengan stimulus maupun sumber stimulus. Sistem saraf merupakan salah satu sistem koordinasi yang bertugas menyampaikan rangsangan dari reseptor untuk dideteksi dan direspon oleh tubuh. Siswa dengan gaya belajar visual cenderung merespon stimulus berupa materi pelajaran dari guru dengan menggunakan indera penglihatan, siswa dengan gaya belajar auditori merespon stimulus cenderung menggunakan indera pendengaran sedangkan siswa dengan gaya belajar kinestetik cenderung merespon stimulus dengan menggunakan alat gerak. Bagian otak yang berfungsi untuk mengontrol respon penglihatan, mengatur sistem pendengaran dan gerak tubuh adalah batang otak bagian tengah.

Hasil analisis hubungan antara masingmasing tipe gaya belajar dengan hasil belajar
Biologi, diperoleh nilai koefisien korelasi antara gaya belajar visual dengan hasil belajar Biologi sebesar 0,551; nilai koefisien korelasi gaya belajar auditori dengan hasil belajar Biologi sebesar 0,463 dan nilai koefisien korelasi gaya belajar kinestetik dengan hasil belajar Biologi sebesar 0,488. Hasil penelitian ini menunjukkan bahwa hubungan gaya belajar visual, gaya belajar auditori, dan gaya belajar kinestetik dengan hasil belajar Biologi masingmasing berada pada kategori cukup kuat.

Menurut Taiyeb \& Mukhlisa (2015), terdapat hubungan antara gaya belajar siswa (visual, auditorial dan kinestetik) dengan hasil belajar Biologi siswa. Siswa memahami gaya belajar mereka sendiri seperti bagaimana memahami pelajaran dengan baik, sehingga mereka dapat menerima materi pelajaran yang disajikan oleh guru dengan baik.

Menurut Ghufron \& Risnawita (2014), setiap individu memungkinkan untuk memiliki satu macam gaya belajar atau dapat memiliki kombinasi dari gaya belajar yang berbeda. Tidak ada gaya belajar yang lebih unggul dari gaya belajar lainnya, semua sama uniknya dan sama berharganya.

Menurut Bire, et al (2014), gaya belajar visual, auditori dan kinestetik merupakan gaya belajar yang dapat mempengaruhi prestasi belajar siswa. Gaya belajar visual, gaya belajar auditorial, dan gaya belajar kinestetik secara bersama-sama maupun terpisah dapat mempengaruhi prestasi belajar siswa.

Hasil analisis hubungan antara kemandirian belajar dengan hasil belajar Biologi diperoleh nilai koefisien korelasi (r) sebesar 0,591. Maka diketahui bahwa hubungan antara kedua variabel tersebut berada pada kategori cukup kuat. Hubungan nyata antara kemandirian belajar dengan hasil belajar Biologi ditandai dengan nilai signifikansi sebesar 0,000. Nilai koefisien determinasi sebesar 34,9\%, berarti bahwa kemandirian belajar siswa memberikan kontribusi sebesar $34,9 \%$ terhadap hasil belajar Biologi.

Hubungan yang cukup kuat antara kemandirian belajar dengan hasil belajar Biologi berarti bahwa jika kemandirian belajar 
yang dimiliki seorang siswa tinggi maka kecenderungan hasil belajar yang diperoleh akan tinggi pula. Siswa yang memiliki kemandirian belajar yang tinggi akan berusaha menyelesaikan segala latihan atau tugas yang diberikan oleh guru dengan kemampuan yang dimilikinya. Oleh karena itu, kemandirian belajar siswa sangat penting untuk diperhatikan dan ditingkatkan oleh guru.

Kemandirian merupakan suatu aspek kepribadian yang sangat penting bagi individu.Bagian otak yang berfungsi sebagai pusat perkembangan kecerdasan, sikap, kepribadian dan ingatan terdapat pada bagian tengah dan belakang otak besar. Namun, pada dasarnya kepribadian seseorang sepenuhnya dikendalikan oleh gen yang ada dalam sel tubuh manusia. Gen tersebut akan bersifat dorman atau tidak aktif dan bersifat aktif. Bila kita sering mengaktifkan gen yang bersifat dorman dengan cara berpikiran positif maka kepribadian kita akan lebih baik, termasuk pula dalam hal kemandiriannya.

Hasil penelitian Rijal \& Bachtiar (2015) menunjukkan adanya hubungan yang cukup kuat antara kemandirian belajar dengan hasil belajar kognitif Biologi, dengan nilai koefisien korelasi yang diperoleh sebesar 0,579.

Seorang siswa dapat dikatakan mempunyai kemandirian belajar apabila mempunyai kemauan sendiri untuk belajar, mampu memecahkan masalah, mempunyai tanggung jawab dan mempunyai rasa percaya diri dalam setiap proses belajar. Kemandirian belajar dapat terlihat pada kebiasaan belajar siswa sehari-hari seperti cara siswa merencanakan dan melakukan belajar (Aini \& Taman, 2012).

Hasil analisis hubungan antara minat belajar dengan hasil belajar Biologi diperoleh nilai koefisien korelasi (r) sebesar 0,755. Maka diketahui bahwa hubungan antara kedua variabel tersebut berada pada kategori kuat. Hubungan nyata antara minat belajar dengan hasil belajar Biologi ditandai dengan nilai signifikansi sebesar 0,000 . Nilai koefisien determinasi sebesar $57,0 \%$, berarti bahwa minat belajar siswa memberikan kontribusi sebesar 57,0\% terhadap hasil belajar Biologi.

Hubungan yang kuat antara minat belajar dengan hasil belajar Biologi berarti bahwa jika minat belajar yang dimiliki seorang siswa tinggi maka kecenderungan hasil belajar yang diperoleh akan tinggi pula. Oleh karena itu, minat yang merupakan aspekkepribadian yang berpengaruh terhadap hasil belajar sangat penting untuk dimunculkan melalui proses pembelajaran itu sendiri.
Minat merupakan suatu sifat yang relatif menetap pada diri seseorang. Dalam menjalankan fungsinya minat berhubungan erat dengan pikiran dan perasaan.Perasaan diproses pada bagian otak yang disebut limbic system atau sistem limbik. Ketika korteks limbik menerima stimulus atau rangsangan, maka dimulailah rangkaian proses pengaturan timbulnya perasaan pada seseorang. Saat kita mulai tertarik pada suatu objek maka hipotalamus akan melepaskan dopamin ke dalam tubuh (neuropeptida yang bertanggung jawab dalam fungsi kontrol perasaan manusia). Efek dopamin ini akan menyebabkan perasaan gembira dan senang.

Penelitian sebelumnya dilakukan oleh Azis (2014) tentang hubungan minat belajar dan hasil belajar Biologi menyatakan bahwa terdapat hubungan signifikan antara minat belajar dengan hasil belajar Biologi pada siswa SMP Negeri 13 Makassar. Menurut Saputra dalam Azis (2014) ada hubungan minat belajar Biologi dengan penguasaan konsep Biologi dengan sumbangan efektif 72,3\%. Mengindikasi bahwa minat belajar Biologi ada hubungan positif yang signifikan terhadap penguasaan konsep Biologi. Semakin besar nilai minat belajar Biologi maka semakin tinggi pula nilai penguasaan konsep siswa, begitupula sebaliknya jika minat belajar Biologi rendah maka akan rendah pula penguasaan konsep Biologi siswa.

Seorang siswa yang mempunyai minat pada pelajaran tertentu dia akan memperhatikannya. Namun sebaliknya jika siswa tidak berminat, maka perhatian pada mata pelajaran yang sedang diajarkan biasanya dia malas untuk mengerjakannya. Hal ini tentu mempengaruhi hasil belajarnya (Khairani, 2014).

Hasil analisis hubungan keempat variabel yang diteliti yaitu gaya belajar, kemandirian belajar dan minat belajar dengan hasil belajar Biologi siswa SMA Negeri 1 Tonra Kabupaten Bone, diperoleh nilai koefisien korelasi (r) sebesar 0,849 dengan nilai signifikansi sebesar 0,000 . Sehingga dapat diketahui bahwa terdapat hubungan yang sangat kuat antara gaya belajar, kemandirian belajar dan minat belajar secara bersama-sama dengan hasil belajar Biologi siswa SMA Negeri 1 Tonra Kabupaten Bone. Nilai koefisien determinasi sebesar 72,0\%, berarti bahwa gaya belajar, kemandirian belajar dan minat belajar siswa memberikan kontribusi sebesar 72,0\% terhadap hasil belajar Biologi.

Berdasarkan hasil analisis regresi ganda diperoleh persamaan hubungan antara 4 
variabel yang diukur yaitu gaya belajar, kemandirian belajar, minat belajar dan hasil belajar dengan bentuk persaman: $\mathrm{Y}=8,731+$ $0,348 X_{1}+0,212 X_{2}+0,482 X_{3}$. Hal ini berarti dengan adanya gaya belajar, kemandirian belajar dan minat belajar, maka besarnya hasil belajar siswa adalah 8,731 satuan; setiap kenaikan nilai gaya belajar siswa sebesar satu satuan, maka terjadi perubahan hasil belajar sebesar 0,348 satuan; setiap kenaikan nilai kemandirian belajar siswa sebesar satu satuan, maka terjadi perubahan hasil belajar sebesar 0,212 satuan; dan setiap kenaikan nilai minat belajar siswa sebesar satu satuan, maka terjadi perubahan hasil belajar sebesar 0,482 satuan.

Hasil penelitian menunjukkan adanya hubungan yang sangat kuat antara gaya belajar, kemandirian belajar dan minat belajar dengan hasil belajar Biologi. Hal tersebut menandakan bahwa hubungan variabel bebas secara bersama-sama dengan variabel terikat lebih kuat dibandingkan dengan hubungan masingmasing variabel besar dengan variabel terikat. Hal ini menunjukkan bahwa terdapat sinergitas antara variabel gaya belajar, kemandirian belajar dan minat belajar siswa. Dalam hal ini, gaya belajar, kemandirian belajar dan minat belajar saling mendukung satu sama lain dalam meningkatkan hasil belajar Biologi siswa. Oleh karena itu, jika dalam proses pembelajaran siswa mampu belajar sesuai dengan gaya belajarnya, memiliki kemandirian belajar dan minat belajar yang tinggi maka siswa akan memperoleh hasil belajar yang tinggi.

Siswa yang memiliki minat belajar yang tinggi akan melakukan aktivitas yang mereka senangi dan ikut terlibat dalam proses pembelajaran. Minat belajar yang tinggi merupakan salah satu faktor yang dapat mendorong siswa untuk belajar mandiri. Mandiri dalam belajar berarti bahwa siswa belajar karena kesadarannya sendiri, mampu berpikir dengan inisiatif sendiri dan mampu menyelesaikan tugas tanpa bantuan orang lain. Siswa yang memiliki kemandirian belajar yang tinggi diharapkan mampu mengambil langkahlangkah penting untuk membantu dirinya agar dapat belajar lebih cepat dan lebih mudah dalam menerima materi pelajaran yang sesuai dengan tipe gaya belajarnya sehingga kecenderungannya siswa tersebut akan mendapatkan materi yang lebih banyak dan lebih bermakna dan akan berdampak positif terhadap hasil belajarnya.

Hubungan yang diperoleh diantara variabel tersebut tidak terlepas dari faktor-faktor yang mempengaruhi hasil belajar siswa. Menurut
Syah (2014), adapun faktor-faktor yang dapat mempengaruhi hasil belajar, yaitu: 1) faktor internal, yakni keadaan/kondisi jasmani dan rohani siswa, 2) faktor eksternal, yakni kondisi lingkungan disekitar siswa, dan 3) faktor pendekatan belajar, yakni jenis upaya belajar siswa yang meliputi strategi dan metode yang digunakan siswa untuk melakukan kegiatan mempelajari materi-materi pelajaran.

\section{KESIMPULAN}

Berdasarkan hasil dan pembahasan penelitian ini dapat disimpulkan bahwa gaya belajar siswa umumnya berada pada tipe gaya belajar visual, kemandirian belajar siswa berada pada kategori tinggi, minat belajar siswa berada pada kategori tinggi, dan hasil belajar Biologi siswa berada pada kategori tinggi. Gaya belajar memiliki hubungan yang kuat dengan hasil belajar Biologi, kemandirian belajar memiliki hubungan yang cukup kuat dengan hasil belajar Biologi, minat belajar memiliki hubungan yang kuat dengan hasil belajar Biologi, gaya belajar, kemandirian belajar dan minat belajar memiliki hubungan yang sangat kuat dengan hasil belajar Biologi siswa SMA Negeri 1 Tonra Kabupaten Bone.

\section{DAFTAR PUSTAKA}

Aini, P, N. \& Taman, A. (2012). Pengaruh Kemandirian Belajar dan Lingkungan Belajar Siswa terhadap Prestasi Belajar Akuntansi SiswaKelas XI IPS SMA Negeri 1 Sewon Bantul. Jurnal Pendidikan Akuntansi Indonesia, 10 (1), pp. 48-65.

Azis, P. A. (2014). Hubungan Minat, Motivasi dan Sikap Belajar dengan Hasil Belajar Siswa Kelas VIII SMA Negeri 13 Makassar. Tesis. Program Pascasarjana Universitas Negeri Makassar, Makassar.

Bire, A. L., Geradus, U., \& Bire, J. (2014). Pengaruh Gaya Belajar Visual, Auditorial, dan Kinestetik terhadap Prestasi Belajar Siswa. Jurnal Kependidikan, 44 (2), pp. 168-174.

DePorter, B. \& Hernacki, M. (2015). Quantum Learning. Membiasakan Belajar Nyaman dan Menyenangkan. Diterjemahkan oleh: Alwiyah Abdurrahman. Kaifa, Bandung.

Djamarah, S. B. \& Zain, A. (2010). Strategi Belajar Mengajar. Rineka Cipta, Jakarta.

Fitriana, S., Ihsan, H., \& Annas, S. 2015. Pengaruh Efikasi Diri, Aktivitas, Kemandirian Belajar dan Kemampuan Berpikir Logis terhadap Hasil Belajar Matematika pada Siswa Kelas VIII SMP. Journal of EST, 1 (2), pp. 86-101.

Ghufron, N. \& Risnawita, R. (2014). Gaya Belajar Kajian Teoritik. Pustaka Pelajar, Yogyakarta. 
Khairani, M. (2014). Psikologi Belajar. Aswaja Pressindo, Yogyakarta.

Marpaung, B. J. R. \& Napitupulu, E. (2014). Pengaruh Strategi Pembelajaran dan Gaya Belajar terhadap Hasil Belajar. Jurnal Teknologi Pendidikan, 7 (1), pp. 25-34.

Rijal, S. \& Bachtiar, S. (2015). Hubungan antara Sikap, Kemandirian Belajar, dan Gaya Belajar dengan Hasil Belajar Kognitif Siswa. Jurnal Bioedukatika, 3 (2), pp. 15-20.

Saleh, H. I., Nurhayati., \& Jumadi, O. (2015). Pengaruh Penggunaan Media Alat Peraga terhadap Hasil Belajar Siswa pada Materi Sistem Peredaran Darah Kelas VIII SMP Negeri 2 Bulukumba. Jurnal Sainsmat, 4 (1), pp. 7-13.

Slameto. (2015). Belajar dan Faktor-Faktor yang Mempengaruhi. Jakarta: Rineka Cipta.

Sudjana, N. (2013). Penilaian Hasil Proses Belajar Mengajar. PT. Remaja Rosdakarya, Bandung.
Sundayana, R. (2016). Kaitan antara Gaya Belajar, Kemandirian Belajar, dan Kemampuan Pemecahan Masalah Siswa SMP dalam Pelajaran Matematika. Jurnal Mosharafa, 8(1), pp. 31-40.

Susanto, A. (2013). Teori Belajar dan Pembelajaran di Sekolah Dasar. Kencana Prenada Media Group, Jakarta.

Syah, M. (2014). Psikologi Pendidikan dengan Pendekatan Baru. PT Remaja Rosdakarya, Bandung.

Tahar, I \& Enceng. (2006). Hubungan Kemandirian Belajar dan Hasil Belajar pada Pendidikan Jarak Jauh. Jurnal Pendidikan Terbuka dan Jarak Jauh, 7 (2), pp. 91-101.

Taiyeb, M \& Mukhlisa, N. (2015). Hubungan Gaya Belajar dan Motivasi Belajar dengan Hasil Belajar Biologi Siswa Kelas XI IPA SMA Negeri 1 Tanete Rilau. Jurnal Bionature, 16 (1), pp. 8-16. 